\title{
Cultural Relics of King of Fire and King of Water in Vietnam's Central Highlands
}

\author{
Dr. Lương Thanh Sơn \\ Tra Vinh University, Vietnam
}

\begin{abstract}
Summary
King of Fire, King of Water whether it is of Cham origin or not is a question for scientists. But the Cham culture, a long-standing culture, left a strong imprint on the central strip of Vietnam. Historically, the connection between the forest and the sea, which is also the connection between the central coast and the highlands of Vietnam, has created conditions for Cham culture to have the opportunity to exchange cultures with the residents of the Central Highlands. Those cultural vestiges, whether verified or not, still show the presence of Cham culture in the Central Highlands of Vietnam with many types of relics that have contributed to understanding the cultural history. Truong Son ethnic groups - Central Highlands with ethnic groups living together in the region create the diversity of Vietnamese culture in the past, present and future.
\end{abstract}

Keywords: King of Fire, King of Water, Central Highlands of Vietnam, Cham culture, cultural vestiges

DOI: $10.7176 / \mathrm{JCSD} / 65-02$

Publication date:July $31^{\text {st }} 2021$

\section{Preamble}

In the traditional society of the Thuong ${ }^{1}$, Regardless of ethnicity, the Thuong people all live in separate villages or hamlets, independent of other villages, between neighboring villages only have friendly relations, marriage, trade... sometimes there are conflicts. If it cannot be resolved, it is a war relationship, but only for a short time. In the absence of the French, the rule in the Central Highlands was completely ruled by the chiefdom. In many regions, there were great chiefs (can be called chiefs), whose power covered a number of villages. or region, more or less depending on the case. According to Y Wang Mlo Duon Du [1]. The chieftains of the tribes in each specific region are as follows: The Ede Kpa tribe has Mr. Ama Y Bley, Ama Y Kon, and Ama Y Jhao. Mr. Ama Y Jhao died in a French prison in 1905; The Ede Bih tribe has Mr. N' Trang Guh, who uses the largest crossbow. The crossbow is too high, each shot must use 3 arrows. That crossbow after N'Trang Guh was captured by the French colonialists, it also collected the crossbow and brought it back to the embassy; The Ede Kiăh tribe has Ama Y Gon, Ama Hap, and Ae Thi; The Ede Blo tribe has Mr. M'Dak; The Ede Adham tribe has Mr. Ama Oal, Ama Ngun, Ama Yang, Ama H'djac, Aê M' Drum; The Ede Krung tribe has Mr. Aê Dla and Mr. M' Kril. Mr. M' Kril also died in a French colonial prison in 1919; The Ede M' Dhur tribe has Mr. Ae H'May, Mr. Ama Y Bleap and Mr. Y Tu (also known as Ama Y Ngoan); The M'nong Rlam tribe includes Mr. Y Bok, Y Krang and M'Dong; The M'nong Prong and Mnong Biat tribes have N'Trang Long, Ama Roy, Ama Bay... Mr. Y Wang Mlo Duon Du has just briefly reviewed the leaders of the Ede and Mnong ethnic groups. In addition, we can also mention other famous leaders such as: Bo Trang Long (N'Trang Long), Oi H'mai, Oi H'phai, Ama So, Ama Jhao, Ama Thuot, Xam Bram, Yă H'Wam, Oi Tǔ, Oi Bŏ, Khundjunob, and Ptâo Pui, Ptâo Ea are mentioned by many people with their legendary character. Researcher Tu Chi said that "a large number of them were probably war leaders who fought against the French when they first arrived in the Central Highlands, but the French, after establishing their power, neutralized them, then eliminated them." gradually give up. At least there was a regime of religious leadership, with the Kings of Fire and Kings of Water... close to the border of lower Laos and eastern Cambodia, and a regime of merchant leaders approved by the French.. So far, no one has studied these different leadership modes to have a head with a wand." [2; 527]. This study mainly investigates the influence of the Fire King and the Water King on the Gia Rai and Ede ethnic groups in the Cheo Reo area.

\section{Research content}

\subsection{The concept of a Leader in the Central Highlands}

Vietnamese - Ede dictionary [3; 605] defines the tribal leader as "Khua djă kǒ djuê mnuih". The chief is considered by the people as "the banyan tree at the head of the stream, the fig tree at the head of the village, the one who looks after the brothers and sisters in the village." People in the village must consult the leader before deciding on something. because "if you have a banyan tree, you must ask a banyan tree, if you have a fig tree, you must consult a fig tree, if you have a mother and father, you must ask your parents", otherwise "there is something wrong that must be brought to trial" [4; 187]. It is from this concept that the trade leader is selected according to traditional standards. The nucleus of the traditional Ede society is the village, the size of which is

\footnotetext{
${ }^{1}$ Thuong is a collective noun for indigenous ethnic groups living in the region including central Vietnam (including the Southeast region, the Central Highlands region and the Truong Son mountain range).
} 
almost the same as that of a Vietnamese village. People living in the village, although there is no clear class distinction, have begun to form classes such as landowners (po roller), waterfront owners (po pin ea), chiefs (mtao). , sorcerer, fortune-teller, sorcerer (po riu yang, popa ge, mjâo), adjudicator (po phat kdi), dik (dweller). In the past, the person who discovered the water source (department of water) was usually the head of the village (the faculty of trade), but in reality, the faculty of trade may have only appeared since the French colonialists placed a colonial yoke in Dak Lak. This position is held by a fixed family in the village, and passed down through the female line, but those who directly hold this position are not women but men, the husband of one of the women of the village. that family or clan. However, simply the person who carries out the duties delegated by the wife. Because, if once the wife dies, the wife's family has no successor, the man must return to his house, has no right to claim any property, nor the role of the pin ea no longer, The wife's family will find a replacement. This person can be the husband of the sisters in the family. The task of po pin ea is to manage and administer the general affairs of the village, preserve the traditional customs and practices and have relations with other villages. However, those who directly hold the post of pin ea are not women but the husband of one of the women in that family or clan. The person holding the position of battery ea often concurrently holds the position of pole roller and even the position of mtao. The Gia Rai people are neighbors of the Ede people, with the same MalayoPolynesian language family, customs and traditions are also matrilineal, inheritance rights belong to the female line, the bride's family gets married, and children are born take the mother's last name. The role of women is mainly expressed in the family, while the role of men is mainly outside the society, which is regulated by customary law. The phenomenon of King of Fire and King of Water in Cheo Reo area, where Gia Rai Chor people live is an example of this problem.

\subsection{Some researchers evaluate the King of Fire and King of Water}

So far, there have been many researchers and writers about these two characters, most of the authors are based on legends, there are a few people who are interested in the fact that they are historical figures, which have been recognized by old histories. recorded a lot.

Researcher Henri Maitre writes: "Certainly these chieftains were originally much more powerful than their present descendants; however, the role of the Sadets should not be exaggerated and assumed that the minor state of Jarai was a kingdom similar to the kingdoms of Cambodge and Champa; Like the "kings" of Che Ma, the Jarai Pataus certainly never had greater power than the equatorial black emirates. This point must be emphasized because it is so often mistakenly assumed that the Sadets were true monarchs similar to the Cham and Khmer kings, with whom they had nothing in common but the easy-going title of "king"[5; 177] and the author states that, "1 Sadet Fire is burned on a bonfire with a selected type of firewood. This distinctly Cham custom persists to this day and is remarkable, as the Moi never cremated the body of a dead person. According to legends to this day, Patau Pui belongs to the Xeu clan (Xiu/Siu) and Patau Ia belongs to the Recham (Ro Cham) family" [6; 179].

Researcher Gerald Cannon Hickey talks a lot about these two kings, about their relationship with the Khmer, but the author also mainly rewrites according to H. Maitre and also comments that: "King of Fire, King of Water can be of Cham origin" [7; 118]. And researcher James George Frazer told about these two kings on two pages with mysticism, he told about life, tools, cremation customs, etc., opening his writing "In the forests of the Central Highlands of Vietnam, he wrote: "In the forests of the Central Highlands of Vietnam French Indochina was inhabited by two mystical kings, known as the Fire King and the Water King. Their fame spread throughout the southern part of the vast Indochinese peninsula, but the West heard little about them. Until recent years not a single European we know of had ever seen either of these kings, and their existence could even be regarded as an allegory, if as if it was not the case that recently they were still in a relationship with the king of Cambodia, every year the king of Cambodia exchanged gifts with them. Their kingships were purely mystical or spiritual; they do not have any political power; they were ordinary farmers living off their hard labor and the gifts of loyal followers. According to one story, they lived in an environment of absolute solitude, never seeing each other and never meeting humans. They in turn resided in seven spiers perched on seven mountains and moved from one tower to another every year. The inhabitants of the area, surreptitiously standing from afar, threw them the items necessary for their survival. The kingship lasted for 7 years, enough time to reside in all the spiers; however many died before that time..." he finally concluded, "So these are examples of what we call the Kings of the natural elements. But there are such kings far from Italy, in the forests of Cambodia and in the springs of the fountain of the Nile. And if we find the Kings of Rain, of Water, and of Fire, we've found a King of the Woods."[8; 185-188]

Researcher Nguyen Chi Ben commented: "Perhaps, the Po tao Pui and Po tao Ya of the Ja Rai people, at first, and after having been refracted to their powerful role in the community, up to now, also is a folk artist. The

\footnotetext{
${ }^{1}$ Henri Maitre (2008), Human forest Thuong - Mountains and forests in the Central Highlands of Vietnam, Tri Thuc Publishing House, Hanoi, p.179
} 
current field survey data with Siu Luynh, who is expected to replace the predecessor Po tao Pui, now in Ayun Pa district is a typical example. Putting aside religious issues, he is a folk artist who has preserved many folklore works of the community from previous generations.[9; 67]

Researcher Nguyen Minh San said: "The Fire King or rather, the Ptao Pui of the Giarai people or M'tao Pui of the Ede people, or ... at first, just a person who mastered the forging industry. tools. But it is because of the admiration and devotion of their own people that gradually bring these people to the place of corruption, becoming the idols of a creed - the belief of worshiping the Fire King. Then, from time to time, the Fire Kings began to take advantage of the beliefs of their fellow citizens, turning them into worshipers. They became shamanic sorcerers. They are mage leaders, not, and cannot be, tribal leaders."[10; 73]

Researcher Nguyen Huu Thau, who has studied for many years about ethnic groups in the Truong Son area - Central Highlands, said that ${ }^{1}$, Russian scientists said that they hypothesized that this man (King of Fire) was a king of indigenous origin, that is, its own society was born. French scientists refer to him as a great sorcerer. He himself asserted that the Fire King was a historical figure that had gradually degenerated until at least the French forced the Fire King to cut ties with Cambodia. Mr. Thau called the King of Fire and King of Water a "priest" or even a "great priest" like an old priest, and a class of people who stood out on behalf of the people to communicate with heaven and earth, not must be a shaman or sorcerer. And there are many other researchers who have given their opinion about the King of Fire, King of Water, they have asked a series of questions such as: are they the Kings of natural elements? are shamans, sorcerers? folk artists? Are they of Cham origin?

I study the above-mentioned King of Fire and King of Water from a historical and cultural perspective, mainly, I combine historical documents with research results of previous scientists to consider and evaluate the problem. subject. I noticed that most of the previous researchers were only interested in the area of influence of these Kings according to the later administrative boundaries and quite a few people believed that the phenomenon of King of Fire and King of Water in Gia Lai province. Hybrid in the Central Highlands - Vietnam. I think that the residence of the Fire King and the Water King is located in the residence of the Gia Rai Chor people, an ethnic group that still retains many traditional cultural elements of the ethnic group and around their residence is still quite good. many cultural traces and oral stories have not been paid attention, especially in the land of Dak Lak in the Central Highlands - Vietnam.

\subsection{The land and people of the ancient Cheo Reo area}

The land of Cheo Reo (Phu Bon / Hau Bon / today is Ayun Pa), is a town located at the confluence of the Ba River and its one tributary, the Ayun River, with convenient roads connecting the central coastal provinces and the Central Highlands region, $96 \mathrm{~km}$ from Plei $\mathrm{Ku}$, and Tuy Hoa. Hoa is $130 \mathrm{~km}$ by road and far from Ea Sol commune, Ea H'leo (Dak Lak province is less than $50 \mathrm{~km}$ ). The Gia Rai (J'rai/ Jrai/Jêrai/Djarai/ Jarai/Gia-rai) are the largest ethnic group in the Central Highlands, with 411,275 people [11] residing mainly in Gia Lai province $(90 \%)$, a part in Kon Tum province and the north of Dak Lak province, in addition, it also resides in the southwestern part of Kom Tum province (5\%), the northern part of Dak Lak province (4\%) and the western part of Phu Yen province. (1\%). At the border between Dak Lak and Gia Lai provinces, they reside in Ea Sup district (Ea Sup/Ea Soup) (Ea Sup town, Ea Rok commune), Ea H'Leo district (Ea Sol commune \& Ea H commune). 'Leo, Gia Rai's population in the whole province of Dak Lak is 16,129 people [12;216].

In the old historical records, it was statistic that the Gia Rai ethnic group includes many groups such as: Arap, Hdrung, Tbuan, Mdhur, Chor, etc. In Dak Lak area, mainly Gia Rai Chor and Mdhur groups reside. . "Gia Rai Chor (also known as Gia Rai Cheo Reo or Phun, Cheo Reo is a compound name from Chu and Chreo, the names of two famous Chiefs of this land at the end of the 19th century, while Phun or Po Phun means). is the origin, which means that the Gia Rai people in this region still retain the traditional characteristics of their people." [13; 98] Gia Rai local groups have their own and unique features, but they share a common culture. In which, the phenomenon of Patau Ia (King of Water) and Patau Pui (King of Fire) specializing in worshiping heaven and earth, praying for favorable rain and wind, of ancient Gia Rai society is common to Gia Rai groups and affects outside ethnic groups. other people in the area such as: Ede, Mnong, Bahnar, Xe Dang,... The Gia Rai people in Dak Lak are ethnic groups residing mainly in the northern districts of the province, concentrated in the districts of Ea Sup, Ea H'Leo, Krong Nang and Ču Mgar. Buon Ta Li (trading on the rock) ${ }^{2}$ Ea Sol commune, Ea $\mathrm{H}^{\prime}$ Leo district is the main residence of Gia Rai Chor people, one of the ethnic groups that still preserve many customs and habits of Gia Rai people. This is the place where the traces of the King of Water and the King of Fire are left, the leaders who have a great influence on the political and cultural life in the Gia Rai residence area. This is also the place where the special festivals of the Gia Rai Chor people take place, contributing to the survival and development of the cultural and spiritual life of ethnic minorities in Dak Lak province. In which, the ceremony of leaving the grave is one of the largest and longest-lasting festivals and also has the most cultural

\footnotetext{
${ }^{1}$ Personal Field Papers, July 1998.

${ }^{2}$ According to Mr. Ksor Quy, Chairman of Ea Sol commune, Ea H' Leo district, April 19, 1998
} 
features in the festivals of the village community. In this region there are many rituals and festivals, usually held after the harvest, which is the transition from the rainy season to the dry season in the Central Highlands. At this time, the farming work is almost over, the rainy season has left and will only meet again after many more months. On the other hand, because after the harvest, the Gia Rai people were able to spend a part of their food to make can wine - a product to worship the gods, and also a drink that is always present in rituals and ceremonies. festival. In all the rituals and festivals of Gia Rai people in Ea H'Leo, the gong is always present in the most important position, is the central instrument of ritual and festival activities, is a musical instrument. "sacred" has a very important position in the spiritual and spiritual life, closely associated with cultural activities and beliefs of the Gia Rai people. Gia Rai people in Ea H'Leo never use gongs without rituals and festivals, because they believe that gongs have the ability to connect with the world of the gods. The gongs of the Gia Rai people in Ea H'Leo district are not used individually, but connected to each other to form a staging, each of which has 3 or more pieces, with different shapes and sizes; The smallest gong has a diameter of $10 \mathrm{~cm}-15 \mathrm{~cm}$ and the largest can be over $90 \mathrm{~cm}$. Gia Rai gong orchestra, is an organized musical instrument, with a fairly tight sound structure. Each gong in the orchestra must have strict compliance with the pitch, nuance, nature of the sound, position in the gong orchestra, rhythm and rhythm when participating in the orchestra. These regulations have existed since ancient times and have become the tradition of the community and of the gong artisans in the villages. The Gia Rai people in Ea H'Leo have many different types of gongs, each with a different arrangement and sound structure such as Mnom, Arap, Trum, Wang gongs. Each gong set of the Gia Rai has its own function in life, and is regulated to participate in different rituals and festivals. These gongs are often used in ceremonies and festivals. In particular, Wang gongs, including Ania gongs, Chiel gongs, and Pot gongs are gongs with knobs, combined with a flat gong called Ding, these 4 gongs form the Wang gong set. This set of gongs is only used in Patau rituals held indoors. Wang's gongs are always placed on the west side of the living room and this is a fixed position in the longhouse. The gong users always face the east window when playing the gong, because they believe that the east direction is the direction of the gods. spirit. Previously, the Gia Rai people residing in the Cheo Reo area had the custom of cremating the dead $^{1}$. The custom of cremation of the dead is carried out as follows: When someone dies in the village, the dead body is placed beside the forest edge of the village in the direction of the wind. Some people went to the forest to cut wood used to cremate the body. Large trees are hammered into the ground into four rectangular corners as support legs, small trees are placed in a layer like a floor. The dead body was laid on that wooden floor. After distributing the goods to the dead, the helpers in the trade piled on top of the body small flammable forest trees. In the evening, the villagers were present in large numbers, the shaman had finished the offerings, the husband or wife of the dead man used a torch to light the fire and cremated the body. While the fire is burning, it is time for everyone to drink alcohol together and dance around the fire. Relatives of the dead sit next to the burning fire and mourn for the dead until the fire dies down. The next morning, relatives of the deceased put the ashes in a small jar and brought them home. From then on, when leaving the house, the wife or husband also carries the jar containing the ashes in his bag. About 2 or 3 months later, they put the jar in a corner of the house on stilts and gradually the jar containing the ashes of the dead was forgotten. This is probably the most primitive way of cremation of the dead of the Gia Rai people, so the Gia Rai in the ancient Cheo Reo region did not have a burial ceremony like other Gia Rai groups. Today, the custom of cremating the dead no longer exists.

The Gia Rai people in Ea Sup district have 796 households, 3581 people, concentrated mainly in Ea Sup town with 689 households (in villages A1, A2, B1, B2, C) and Ea Rok commune with 101 households. M'Thal village) is still scattered in communes in the district. The Gia Rai people in Ea Sup district belong to the Chor . group $^{2}$ originally from the Plei Kli vùng region ${ }^{3}$ (Gia Lai province) they migrated for 3-4 generations, the Siu family was the first to explore this land, taking the name Ea Sup stream and named it Plei Sup. Floods affect people's lives, rice, pigs, chickens, and some households living near the river were swept away by floods; The raging epidemic affected the health of people in the village, many people died due to diseases, constant poverty, there was a time when Gia Rai people in Plei Ngŏ and Plei Kyoa left here to live in Cambodia like in 1962., 1963, but then the village head Y Thong Hra (Ama Phit) came to welcome them back and divided Plei Sup into 3 villages: Plei Ngŏ (Eastern village), Plei Yố(Western village), Plei Kyoa (inland village). Between). In 1977, a district of three villages was established, which was rearranged by the government to live close to each other and named it as village $A$, village $B$, and village $C$. Later, the population increased, so they separated and added a new village as it is today ${ }^{4}$. Gia Rai people in Ea Sup also keep cooking traditional dishes of the community. In the past, when salt was scarce, people made a kind of salt to eat from green beans by burning the mung bean pods, then filtering the water and using it instead of salt. The spice instead of monosodium glutamate is a sweet-

\footnotetext{
${ }^{1}$ According to Mr. Ro Cham Chao (Ae Ly), self-reported as Ede Adham, Chu village (Ču), Ea Sol commune. Ea H'Leo district, Field document dated 19/4/1998.

${ }^{2}$ According to Kpa Simon, Gia Rai ethnic group, 58 years old, Tan Thanh ward, Buon Ma Thuot city, provided on 11/18/2016.

${ }^{3}$ According to H'Hut Siu (Ami Phit), Gia Rai ethnic group, 77 years old, village B1, Ea Sup town, Ea Sup district, November $27,2016$.

${ }^{4}$ Currently, there are 5 wholesalers, namely A1, A2, B1, B2, C.
} 
tasting forest leaf (la jao), about twice a week, it is cooked with nam peng (hearing soup), nam pung (powder soup). In family, clan, and village occasions, there are festivals, especially in weddings, burial ceremonies, compulsory traditional dishes such as nam pung (powder soup), lap dish and tai lap dish. In the worshiping ceremonies, the shaman must always call the names of the Gia Rai chiefs, especially the Siu family.

\subsection{Cultural vestiges of the Fire King, the Water King in the ancient Cheo Reo region} Back to the past

The Cham people were present in the Central Highlands quite early, according to legends, they came to trade salt in exchange for forest products, exploiting agarwood, minerals, some ran wild...but it can also be assumed that, The origin of the Fire King was originally a prince of Champa country by King Le Thanh Tong of Vietnam set as king in Nam Ban country (Cheo Reo, Cung Son, Krong Pa, Song Hing and above, we can predict guess so). Cheo Reo region in the old history, history also records, after the victory of Champa, Le Thanh Tong extended the border of Dai Viet at $\mathrm{Cu}$ Mong pass (between Phu Yen and Binh Dinh) the rest of the land of Champa from Phu Yen Returning, Le Thanh Tong divided into 3 countries: Nam Ban, Hoa Anh, and Chiem Thanh. Nam Ban country [14;1100-1101], the old history records that, formerly it belonged to the land of "Chiem Thanh, when King Le Thanh Tong conquered Champa and opened the land to Thach Bi mountain $[15 ; 1101]$ After naming the descendants of the old lord Chiem Thanh as King Nan Ban Quoc and dividing the land between Thach Bi mountain to the west, from Hoai Nhan's palace following the upper path [16;1104], it took 14 days to reach this country. It is the land of the two countries Thuy Xa and Hoa Xa.’[17; 1101].

In Phu Bien Tap Luc by Le Quy Don, it is described in more detail: "There are more than 50 villages in that country, in the country there is a very high Ba Nam mountain, a town in one direction, Thuy Vuong in the east of the mountain, Hoa Vuong. In the west of the mountains, all have their own territory, guarding trees to build houses, belonging to several hundred people, plowing with knives, planting by fire, sowing in January, and May when rice is ripe, not reaped but only plucked, do not know the date. After threshing, the tax is collected. The king rode an elephant with more than ten people, and when he reached a barbarian village, he beat three times the people in the village came out and built a cottage for the king to live in" $[18 ; 122]$. Thus, the assumption that Patao Pui belongs to the royal line of the old Champa kingdom set by King Le Thanh Tong is valid. If counting from 1475 onwards, there are a total of 525 years, if counting each king's life for about 25 years, there are about 20 kings, that is, there are about 7 generations that we can't remember.

According to the documents of the pre-Nguyen dynasty, descendants of the Nguyen dynasty entered Quang Binh to settle down, in the middle of the 16th century, the Nguyen Lord still had relations with Patao Pui, once every few years Patau Pui gave people to the court to pay tribute. Lord Nguyen also gave Patau Pui a rank of three martial arts officials until the Nguyen Dynasty ascended the throne to continue their relationship. "The 1st King Minh Mang (1851) sent the Thuy Am mission to the capital to offer tribute and at the same time gave Thuy Xa: 2 pieces of Song Dynasty brocade, two pieces of dance, two stacks of truss... for the ambassador: platinum ten taels, one piece of truffles, two pieces of cinnamon, three pieces of color..." [19; 180], In the 15 th year of Minh Mang, the king also gave Thuy Xa: "a porcelain tea set, a crystal wine drink set, a crystal box painted with gold thread, including a plate, and a box of crystal silhouette, two statues of people in red onyx..."'[20; 180]. The mandarins of Phu Yen province, obeying the orders of the Nguyen Dynasty, gave Hoa Xa "a single silver urn for later storing the ashes of Hoa Xa's body" [21; 180].

Researcher Nguyen Huu Thau (specialist in the study of ethnic groups in Truong Son - Central Highlands) recounted that, He once met the descendant of the Fire King, Oi Luan, to find out the problem, before he was told that Oi Lun had to use a cup of wine to worship and pour it on the ground, and then Oi Luan told that his family was not There must be only one sword, but there are many. People make a tent in the forest and keep their swords in it. The three in the middle are the god swords, the last three and the first two are called k'eng, which are considered assistants to the other swords. On the table in the tent there was also a basket in which the rings were considered sacred. There is also a bronze bell (now lost) and tools for catching elephants. Talking to me, Mr. Nguyen Huu Thau commented, "Could these swords be given by the feudal court?".

About the King of Water and the kingdom of Thuy Xa: King of Water Village is located in Nhon Hoa commune, about $20 \mathrm{~km}$ from the center of Chu Se district, in Gia Lai province. The legend of the king of the country says that, when Yang Ju H'mang and Yang Chu fought, Yang Ia intervened and was trusted by the Jade Emperor to govern the villagers. Yang Ia stayed in the heavens, wanting to govern the villagers well. Yang Ia asked the Jade Emperor to set up another intermediary level, the Water King (Po tao Ia) to govern the world. The first crown was given to the Cham people, later the Gia Rai people of the Ro Cham family won the crown. Therefore, the Cham people have come to fight many times to reclaim the crown. The king of water is the representative of the world in contact with the gods in the physical world, the king is contributed money by the villagers to build a house, and the subjects voluntarily produce to feed the king. The king only did one thing, was to pray to heaven for favorable weather, healthy people, and prosperous business.

Until 1955, the king's family had gone through 7 kings, the 7th king died, his body was cremated very 
solemnly, like the Cham Brahmins in the Central Coast. The king's body was left on the pyre during the funeral, which lasted 7 days and 7 nights. During this time, the villages make sacrifices with cows and cows. After 7 days, the villagers took the ashes and buried them right under the tomb, and they also distributed the property to the king. The king's tomb was built as a miniature communal house in a separate area, not together with the village's tomb. Only the king's wife was buried nearby. During the funeral, people from far and near villages all attended, the Gia Rai people in Plei Ku, Chu Prong, Duc Co (Gia Lai province), the Ede and Gia Rai people in Buon Ma Thuot and Buon Ho (province). Dak Lak) came in large numbers. The king of the 7th generation has a property left behind is a magic sword hidden in the sacred forest that only the king and his servants know, and the two bells and the king's clothes are left by the descendants of the Ro Cham family in Tsam village. Ea H'Leo district, Dak Lak province is being kept. If you want to see the sword, you have to sacrifice it with a pig ${ }^{1}$.

The relationship between Hoa Xa and Thuy Xa dynasties and the lowlands was mainly through merchants and their stories were only oral stories in folklore. However, based on ethnographic literature, we hypothesize that, Patau Pui, Patau Ia/Ea are descendants of the king of Nam Ban for the following reasons:

Firstly, before that, some people thought that they were born in the heart of Gia Rai society, but we think that they are the remaining descendants of the deformed King Nam Ban. Because, the custom and enthronement ceremony of the Fire King is usually held at Drang Lai "Drang Lai is a temple located $4 \mathrm{~km}$ from the fortress (Cheo Reo), on the right bank of the Ayun River is a small temple dedicated to Siva, built built on a mound of land. According to Finot and G. Maspero, Sinhavarman III built for the god Siva Jaya Sinhavarman lingaciara in Panduranga (Phan rang) and Dak Lak today. The temples they generously endowed with land, slaves and elephants..."[23; 201]

Second, in the past, dead Pataus were usually cremated, not buried. "When hearing the news that Hoa Xa had just come up, the Nguyen Dynasty sent the officials of Phu Yen province to congratulate them and give them a silver urn for later storing the ashes of Hoa Xa's body... after that, it was placed on a wooden truss. and then make a cremation ceremony like the Cham people."[24; 181]

Third, wherever the Patau Pui go, they usually have an entourage followed, their costumes are all white. Although the king was very prestigious with the villagers, every time he went to the village he had to stay in the forest. Le Quy Don wrote: "Whenever a king enters a house, that house is not good, so the king does not dare to enter anyone's house. The number of people who are more or less willing to hand over a copper pot, a white cloth, a sugarcane, a banana tree, take it without taking notes, take it and go elsewhere."[25; 122]

\subsection{Traces of material and spiritual culture of the Cham people in Dak Lak}

Whatever the legend, the presence of the Cham people is real, they have left cultural heritages in the Central Highlands, especially in Dak Lak, there are many things to discuss. The first trace that must be mentioned is a fairly intact tower, located about $100 \mathrm{~km}$ northwest of Buon Ma Thuot city, on the Ea H'Leo river, in the territory of Ea Roc commune, Ea Sup district, although although it is only about 14 kilometers from Plei Tali as the crow flies. People here call it Yang Prong tower which means big god. According to old history, Yang Prong is an ancient tower of the Cham people in the past, built by the Cham king Sinhavarman III in the late 13th and early 14th centuries, the Mukhalinga worship tower prays for the proliferation of the race and prays for the future. Warm, full, and happy, symbolizing fertility. Regarding this statue, according to H. Maitre's report on two visits to the tower (1906 and 1910), the only remaining object in the tower is a stone linga. On the head is carved a ceremonial cap, placed in a mu kha "bath basin", collectively known as mukha - linga[26; 218]. In 1991, this statue was no longer there, according to the villagers of Tali (old) ie nearby Ea Thal village, in 1938, the French came and forced the villagers to carry the statues in this tower area. brought to Buon Ma Thuot, they had to carry a lot $(?)^{2}$.The testimony of the witness more than 20 years ago was confirmed by the altar (mukha) found in April 2011 (no linga was found) in Buon Ma Thuot, the former working place of the French Embassy. This altar has the form of Ioni, the square side is $102 \mathrm{~cm}$, the thickness is $25 \mathrm{~cm}$. We suspect that this mukha belongs to the Yang Prong tower, for the following reasons: Firstly, the Yang Prong tower currently does not have a mukhalinga statue as described by H. Maitre. Second, based on the story of Ama Preo, who was directly carrying the statue. Third, the statue was brought to Buon Ma Thuot, where the French legation was located. Fourth, compare the found artifact with $\mathrm{H}$. Maitre's drawing of the stone mukhalinga of the interior of the tower. Fifth, numbers and words are engraved on the altar: 1934 and RENUCCI. We learned about the inscription on the pedestal of this altar and learned that it is the name of a long-standing family in the French island of Cooc. The person who told us this further commented that, surely the person who engraves the artifact is not a scientist, if a scientist never engraves the object, it is probably a soldier of that clan[27; 739]. As for the year, perhaps Ama Preo mistakenly remembered 1938, because when we met him in 1990 he was 95 years old. Maybe when the French withdrew, they brought the linga with them because it was small and compact, and the mukha was too

\footnotetext{
${ }^{1}$ According to Ama Hiu from Tsam A village, Ea H'Leo commune, Ea H'leo district. April 29, 2000

${ }^{2}$ The person we approached on October 21, 1990 was Ama Preo, an ethnic Gia Rai, 95 years old in village C, Ea Sup commune, he was directly carried the statue.
} 
heavy to bring back to France, so it was left at the Embassy? We think that Yang Prong belongs to the Cham people after we found the pedestal of the statue. Perhaps, the birth of the tower at that time spoke of a period of development of the Cham people in Dak Lak in particular and the Central Highlands in general. The value of the tower is that it is a physical trace of history. about the presence of the Cham people in Dak Lak in the past.

Through the architectural design and worshiping objects in the tower has shown us [28], Yang Prong Tower is a harmonious combination between ancient Cham architecture and the cultural features of local residents, namely Gia Rai people, Through the artifacts found around the tower, it is the terracotta bird heads that are not like in the drawings of $\mathrm{H}$. Mettre but seem similar to the grizzly bird statues carved in the grave sites of people in the area.

\subsection{Other vestiges of the Cham people and folk tales still exist in some areas of Dak Lak.}

The area of Ea Ktur commune, Č $u$ Kuiñ district adjacent to Hoa Thanh commune, Krong Bong district since the early 1990 [29], discovered ruins, an area of about 40 square meters, with many common types of bricks, which are rectangular bricks and two-sided beveled bricks like those found in Yang Prong (Ea Sup district), because Because of the cultivation of crops, it is difficult to identify this as the base of a tower or a brick kiln, about 100 meters to the north there is another ruin about 9 square meters that has been leveled and people have dug holes to plant coffee. On the surface, there are still a lot of broken tiles on the surface, some of which are decorated with stylized leaves. Not far from that ${ }^{1}$, There is another ruin with an area of about 100 square meters, nearly $1 \mathrm{~m}$ high above the ground, here, when digging down to $0.40 \mathrm{~m}$, a resident ${ }^{2} \mathrm{We}$ have found a piece of stone with writing (like Cham letters) on both sides, we suspect it is like a piece of inscriptions, around the ruins are mounds like tombs arranged consecutively. People here circulate the story of 6 tombs of 6 Cham king brothers (?) who lived 600 years ago (?) with many valuable treasures buried. They also said that from time to time (1991) there were still a few Cham people selling drugs or passing through this area to find something (?). Right at this ruins, a few years later, people discovered other artifacts such as a ceramic bowl with a lid, or a stone column (looks quite like a lingo) on which a Buddha statue was carved. sitting cross legged... In Hoa Thanh commune, Krong Bong district, a bronze alloy statue's head was discovered in the field of a local house, the head of the statue is $15 \mathrm{~cm}$ high, the hair part is $7 \mathrm{~cm}$, the hair of the statue is in a high bun. There are 3 strands of spiral hair hanging down, the statue's eyes are wide open, the nose is straight, the nose is wide, the lips are thick and curved, the forehead is wide and high, the statue is wearing a crown, sitting cross-legged on a lotus. Later, the museum's staff came to survey this area and discovered some suspected places that it might be the relics of the Cham people and collected some other relics such as bricks, tiles..

Another place in Hoa Phu commune, on the outskirts of Buon Ma Thuot city, right at the beginning of bridge 14, there is also an area for people to live. ${ }^{3}$ Discovered many artifacts including a stone Buddha head and stories about the Cham people selling drugs or passing through this area.

In Ea H'Leo commune, Ea H'Leo district, people mentioned H'Bia Pe with three legs ${ }^{4}$, located on a road of the Cham people speaking from West to East in the commune from the central coastal region. H'Bia Pe means princess, there are places such as: $\breve{C} u$ Bap Mtien in Cham village, Put river in Ea H'Leo commune; Ea Kmok stream is in the middle of Tu Kuk and Tu Pah areas, you can follow Tu Mot road with many bronze pot-shaped stones, elephant heads, human footprints ${ }^{5}$..

In Ea Sol commune, Ea H'Leo district, people have told about the legend of the Fire King as follows: During the French occupation, the king used to walk, when My Wei had a car and saw him walking, they picked him up and the car fell. he never walks behind other people, he usually goes by handcart. The French admired him because he did not drop a single drop of water in the basket and promised that 10 days later it would rain and the Ayun Pa river would overflow where he planted the tree, all as he had said. Here, they also said that the Fire King family lived in Cham village in Ea Sol commune (commonly known as Buon H'Yoan Cham). Buon Hieo, Ea Rbong commune in Ayun $\mathrm{Pa}$ (also known as H'Yoan Hieo village) still has the blade, and annually washes the aforementioned objects at the foot of the mountain $\breve{C} \mathrm{~B}$ Bah (?).

In Ea Trang commune, Mdrăk district, there is also a story about an area with many beautiful carved stones, etc. Perhaps these are just myths, rumors without foundation, but we still want to cling to it to find other mysteries that exist in the daily life of people in different regions. The area of influence of the Fire King and the Water King.

\footnotetext{
${ }^{1}$ The site of discovery is Team 3, Ea Knuech village, Ea Ktur commune, Krong Ana district (1991).

${ }^{2}$ That is Mr. Le Ngoc Vinh, born in 1958, from Duc Tho, Ha Tinh, in 1991 he was a worker on a Vietnamese - German coffee farm. Personal fieldwork.

${ }^{3}$ It is the field of Mr. Huynh Trong Ngan's house, village 10, Hoa Phu commune, Buon Ma Thuot city.

${ }^{4}$ Word by Secretary of the Commune Party Committee Ama Hanh (Y Nho), March 29, 2000

${ }^{5}$ The story of Ama Bǔ in Tsam B village, Ea H'Leo commune, Ea H'Leo district, March 29, 2000
} 


\section{Conclusion and comments on the research results}

The old history records that King Porome of the Cham people (1624 - 1654) had a wife, H'Bia Than Chan [30; 27], there are books that say her name is Bia Than Cih [31; 252]. Mr. Truong Dai Tho, born in 1954, Cham, residing in Hau Sanh village, Phuoc Huu commune, Ninh Phuoc district, Ninh Thuan province, who is the caretaker of the tower, recounted that her name is H'Bia Tha Kchan, H. 'Beer literally means a beautiful girl (figuratively a princess), and Tha Kchan, literally follows a footprint, figuratively faithful. Tha Kchan is a faithful wife to her husband, because when her husband died, H'Bia Tha Kchan volunteered to die with her husband $[32 ; 189]$. Currently, in Ninh Thuan, there is a tower to worship King Po Rome and Mrs. H'Bia Tha Kchan. King Porome is worshiped here, but it is recorded that he was born in 1627 and died in 1651. Legend of King Porome [33] There is a mention of a character that is Mr. Hoang Phi Kchok, who is the son-in-law of King Porome (married the first daughter of King Porome with Mrs. This son-in-law betrayed his father-in-law, conspiring with Lord Sai (Nguyen Phuoc Nguyen, 1613 - 1635) to harm his father. Phi Kchok later is not mentioned in the legend. But does Phi Kchok have anything to do with the Bih self-proclaimed name Pih K'Cho as Besnarrd mentioned in 1922? Or just a homophone? and in the 17th century, a Cham emperor led his 5,000 subjects through the land of Dak Lak [34;66] Does it have anything to do with Mr. Hoang Phi Kchok today? Another document states that "King Po Rome (reigned from 1627 - 1651) was a resident of the village of Byuh in Dong Nai, that is, a mountainous region where many non-Champa ethnic groups lived, ascended the throne in 1655. Is the son of the daughter of his wife Ede or Koho married to Po Rome"1. Just scattered, vague, unconvincing thoughts, but one question persisted in me: So how are the Cham and the Bih related to each other? This may just be a rather vague hypothesis that has not been tested.

Through the survey, we found some similarities between the Bih people and the Cham people as follows: Firstly, about the name Bih or Abih clan in the Cham's sense of the end, the end, the end of nothing. , is abih talking about the last Cham people, who have now become the official name of the Bih people in the Central Highlands today? Abih, in the Malay language - Polynesian means the end, or nothing left. When reading and swallowing the sound a, like ama, ami (read as ma, eyelid), over time the sound a has dropped into Bih and has no meaning (!!!). Secondly, in terms of language, both of these ethnic groups have the same language origin as Malayo - Polynesia, the results of lexical statistical comparison (based on 2,200 basic words) of the Bih group's language compared with the Kpă group's language (main Ede group), the similarity rate is $73 \%$, according to the results of the survey on language by Nguyen Quoc Loc $[35 ; 30]$ The Ede people have about $84 \%$ of words close to the Cham and Gia Rai people. One can also base on the morphological characteristics, the process of transforming from a polysyllabic language with suffixes to a monosyllable language without affixes, the voice of the Bih group belongs to region II, this is of the local group also bears the clear impression of a polysyllabic language in the process of monosyllabicization; author Dam Bo, writing "in the south of the Ede region, the Bih speak the Cham language"[36; 49]; "The Bih people in southeastern Dak Lak are the Cham-speaking people." [37; 57]. Third, about the terracotta craft of the Bih people, the way to make pottery without a turntable, open-fired, and especially shape products from coils is no different from the workers in Bau Truc (Ninh Thuan) ${ }^{2}$.

The bronze drum is a precious antique in Vietnam, often considered a musical instrument of ancient Vietnamese residents. In Dak Lak province, since 1984, 16 bronze drums have been discovered. Of which 14 drums are kept by the Dak Lak Museum, the remaining two drums: A discovery in 1984 is privately owned and a discovery in 1998 is being kept by the Phu Yen Provincial Museum. Dak Lak bronze drums are concentrated in the Northeast and Southeast regions of the province, bordering two provinces of Phu Yen and Khanh Hoa.

Among the drums currently known in Dak Lak, there are 4 drums found in the drum with human remains and jewelry, for example: a bronze drum discovered in Ea Pan commune, Ea Kar district has human bones inside, some objects stones, some copper jewelry bracelets and small onyx beads. Some bronze drums found in Krong Pac district also have similar decorations. In Ea Kar district, inside the drum were found a bracelet and a wrist bone. We believe that the Dak Lak bronze drum is not only a musical instrument, but also a coffin for the deceased [38; 211-212]. In a sense, the bronze drum coffin here is similar to the type of jar tomb in the Sa Huynh culture in the central coastal region. Some questions arise: How did the ancient Vietnamese bronze drum appear in the Central Highlands? Who is the owner of the remains and burial items in these bronze drums? The ancient Vietnamese directly traded and exchanged with the residents of the Upper region or through other merchants, who was that trader? It is hypothesized that, 2000-2200 years ago in the Central Highlands, there were ancient Vietnamese people. This hypothesis needs more verifiable documents, especially anthropological documents. However, the Central Highlands in the early years of the Common Era was a community of many ethnic groups, and cultural exchanges between ethnic groups were natural, even in the belief of "animistic things", a common background of many ethnic groups here. In our opinion, the appearance of artifacts accompanied by drums has a very important meaning, it allows us to think of a certain cultural exchange that happened in history? Who is the

\footnotetext{
${ }^{1}$ Sakaya (2004), Contributing more Champa documents about Cat Tien holy land (Lam Dong), Journal of Archeology (2), pp. 66.

${ }^{2}$ Personal fieldwork in Ninh Thuan, 2004.
} 
owner of those jewels? Was that type of jewelry ever used by the ancient Vietnamese? Or was there a certain ethnic group as an intermediary, trading with the ancient Vietnamese, and then the drum appeared in the Highlands? We suspect that maybe the Cham people, who have a talent for trading, have traveled around the country many times in history, having migrated to the Highlands many times, have done this? Through the historical relationship between the Cham and the Montagnards and the jewelry in the drums, we suspect that the owners of the above-mentioned empty tombs are of the Cham ancestors.

In Dat Ly commune, on the outskirts of Buon Ma Thuot city, a grinding pestle table was also discovered (which is being kept at the Dak Lak Museum), many thought that it belonged to the Cham people.

The documents that we have not found in the old history are the rasung-batau (?) in Buon Ma Thuot; The records of $\mathrm{H}$. Maitre in the early 20th century around Yang Prong have not yet resulted in a serious archaeological excavation to find the inscriptions on the lids and other mysteries of the tower that have been buried over time. time; Why did the Cham people almost disappear from the plateau while the legend of the Gia Rai people once said that the Cham people were so numerous that they were like "sesame seeds" in a basket full of sesame seeds?

\section{REFERENCES}

[1] Y Wang Mlo Duon Du (1987) Preliminary history of Dak Lak province, Typed document, archived at the Dak Lak Party Historical Research Sub-Committee.

[2] Nguyen Tu Chi (1996) Contributing to the study of culture and ethnic groups, Publishing House of Culture and Information - Journal of culture and art, Hanoi, p. 527.

[3] People's Committee of Dak Lak Province, Department of Education and Training, Institute of Languages, Vietnamese - Ede Dictionary (1993), Thanh Thao Printing Facility, p. 605

[4] Ede customary law (French custom) (1996), National Political Publishing House, Hanoi, 1996, pp.187.

[5], [6] Henri Maitre (2008), Montagnard forest - Central highland forests, Tri Tri Publishing House, Hanoi, p. 177

[7] Gerald Cannon Hickey (1982), Sons of the Mountains (Ethnohistory of the Vietnamese Central Highlands to 1954), Yale University Press, New Haven and London, p. 118

[8] James George Frazer (2007) Golden Branch, Encyclopedia of Primitive Cultures, Culture and Information Publishing House- Culture and Arts Magazine, pp.185,188.

[9] Nguyen Chi Ben (1993) The appearance of Gia Lai folklore - an outline, Journal of Arts and Culture Research, No. 2, p. 67.

[10] Nguyen Minh San (1993), Around the phenomenon of religious culture "King of Fire" in the Central Highlands, Journal of Arts and Culture Research, No. 2, p. 73.

[11] General Statistics Office (1999), Population and Housing Census.

[12] Provincial Party Committee, People's Council, People's Committee of Dak Lak Province (2015) Dak Lak Geography, Social Science Publishing House, pp.216

[13] The Central Highlands of Nature and People (1987), Education Publishing House, H., p. 98

[14] [15], [16], [17] Kham Dinh Viet Su Thong Giam Cuong Muc (1998) Chinh Bien - Volume XXII, Education Publishing House, Volume 1, pp. 1100 - 1101.

[18], [19], [25] Le Quy Don (1977) Phu Bien Tap Luc, full episode, Volume 1, Science and Technology Publishing House, H., p.122

[20], [21], [22], [24] Hoang Van Huyen (1980) Central Highlands, Culture Publishing House, District, p.180

[23] Jacques Dournes (1970) Recherches sur le haut Champa (Learning about Upper Champa), France - Asie, T.XXIV, Vol 2(201).

[26] H. Maitre, Les régiens Moi du Sud Indochinois Le Plateau du Dar lac Paris, Plon Nourrit et Cie, 1909 , p. 218.(The author also attached a picture of the stone mukhalinga in the interior)

[27] Luong Thanh Son (2012) The altar of the Cham tower Yang Prong, New findings on Archeology in 2011, Social Science Publishing House, H. p.739.

[28] Luong Thanh Son (1991), Cham Towers in Dak Lak, Journal of Ethnology, no. 3.

[29] Luong Thanh Son (1991) Cham ruins in Ea Knuep village, Ethnographic Journal, No. 4.

[30], [32] Ngo Van Doanh (1994), Truth and Legend of Cham Ancient Towers, Culture and Information Publishing House, H., p. 27.

[31], [34] Sakaya (2003), Festivals of the Cham, National Culture Publishing House, H., pp. 252.

[33]Nguyen Van Luan (1974), Muslim Cham people in the southwestern part of Vietnam, Bookcase of editors, Ministry of Culture and Education, Youth Publishing, Saigon.

[35] Be Viet Dang, Chu Thai Son, Vu Thi Hong, Vu Dinh Loi, (1982), Outline of Ede and Mnong ethnic groups in Dak Lak, Social Sciences Publishing House, p.30

[36], [37] Dam Bo (Jacques Dournes) (1950, Translation by Nguyen Ngoc in 2003), Fantasy land, Writers' Association Publishing House, p.49 
[38] Luong Thanh Son (2012), Bronze drum related to burial custom. Institute of Archeology, Archaeological Findings 2011. Social Sciences Publishing House, H., pp.211-212. 